\section{KUI SÕNA OLI EKSLIK}

Vene keele ja filoloogia peensustes võhikuna andsin formalismikogumikku${ }^{1}$ toimetades endale aru, et uisutan õhukesel jääl, kuid lohutasin end mõttega, et säärane avantürism polnuks võõras ka formalist Viktor Šklovskile. Seda rõõmustavam on, et Silvi Salupere leiab raamatu olevat nauditava ning toob välja kõigest tosinkond tõlke- ja tõlgendusküsitavust. $^{2}$ (Neist kõige piinlikum on väljendi естественно-исторические ümberpanek „esteetilis-ajaloolisteks” „looduslooliste” asemel - raamatu aparatuuris, lk 334.) Rõõmustav pole see, et Salupere märkustest pooled on ise eksitavad.

Seoses järelsõnas tsiteeritud Lev Trotski formalismivastase retoorikaga „Nad on johanniidid: nende jaoks „alguses oli sõna"” (lk 360) märgib Salupere: „..., ,johanniidid” ei ole mitte XI sajandi ordu, vaid $\mathrm{XX}$ sajandil tekkinud vene sekt, nimetatud Kroonlinna Joanni järgi, ja peaks olema ,joanniidid" ". ${ }^{3}$ Formaliste johanniitideks (ehk johanneslasteks) sõimates ei mõlkunud Trotskil meeles ei XI sajandi ordu ega XX sajandi sekt, vaid hoopis Johannese evangeeliumi avalause. Seega polnuks õige luua seost XX sajandi sektiga.

Põhjendust andmata peab arvustaja „lugejat eksitavaks veaks” millegipärast seda, et „Kirjandusfakti” alguse kommentaaris (lk 331) nimetatakse Juri Tõnjanovi hämarat poleemikat hämaraks poleemikaks.

${ }^{1}$ Kirjandus kui selline. Valik vene vormikoolkonna tekste. Koost ja toim Märt Väljataga. Tallinn: Tallinna Ülikooli Kirjastus, 2014.

${ }^{2}$ S. Salu p e re, Kui sõna oli tegu. - Keel ja Kirjandus 2016, nr 2, lk 135-138.

${ }^{3}$ Samas, lk 137.
Salupere pole rahul mu seletusega: „,Rida” (ряд) on formalistide (eriti Tõnjanovi ja Eichenbaumi) termin kultuurilise süsteemi ehk faktiseeria jaoks" (lk 333). Ta ütleb: „Kumbki autor ei väida midagi niisugust, rääkimata kultuurilise süsteemi samastamisest faktiseeriaga, nad isegi ei kasuta selliseid väljendeid." "Kuna Tõnjanov ja Eichenbaum „rida” minu teada kuskil otsesõnu ei määratle, pidin andma tõlgenduse. Salupere jätab ütlemata, mis on tema meelest „rea” tõeline tähendus formalistidel, kui see pole kultuuriline faktiseeria ega süsteem.

Boriss Eichenbaumi „Kirjanduselu” algus erineb eri publikatsioonides ühe tähe poolest: „Мы видим не все факты сразу, не всегда видим одни и те же и не всегда нуждаемся в раскрытии одних и тех же соотношений. Но/Не все, что мы знаем или можем знать, связывается в нашем представлении тем или другим смысловым знаком - превращается из случайности в факт известного значения." Seega teist lauset saab tõlkida kahte moodi: „Kuid kõik, mida me teame ja teada saada võime, seostub meie kujutluses mingisuguse mõistelise märgiga [resp. kontseptsiooniga], mis muudab selle juhusest kindla tähendusega faktiks” või „Mitte kõik, mida me teame ja teada saada võime, ei seostu meie kujutluses....” Salupere väidab, et „teksti loogika viitab just teisele variandile, sest sel juhul on kaks esimest lauset mitte vastanduses, vaid järgnevuses", 5 kuid ei täpsusta, miks on järgnevus loo-

\footnotetext{
${ }^{4}$ Samas, $1 \mathrm{k} 138$.

${ }^{5}$ Samas, lk 137.
} 
gilisem kui vastandus. Esimese variandi kasuks valides lähtusin mina niisugusest loogikast: esimene lause puudutab

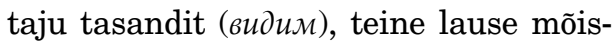
telise tunnetuse ehk teadmise tasandit (знаем) ja Eichenbaum tahab öelda, et meie pertseptiivne tunnetus jääb ebamäärseks, kuni seda ei kontseptualiseerita teadmiseks. Ma ei söanda väita selle tõlgenduse ainuvõimalikkust, aga Salupere jätab oma eelistuse põhjendamata.

Salupere kirjutab: „Eksitav on lk 352 paiknev allmärkus 16 , kus öeldakse, et „Jakobson samastas selle [s.o poeetilisele keelele olemusliku $-M$. $V$.] funktsiooni algul ekspressiivse funktsiooniga, aga hiljem postuleeris omaette poeetilise funktsiooni". Siin on segamini aetud kaks asja - poeetiline keel ning Jakobsoni kommunikatsioonimudel." ${ }^{\text {Siin }}$ pole mitte midagi segi aetud: Jakobson

\footnotetext{
${ }^{6}$ Samas, lk 138.
}

kaldus varases vihikus „Новейшая русская поэзия” (1921) tõepoolest samastama poeetilise keele olemust keele väljendusliku orientatsiooniga.

Salupere jätkab: „Ka ei tohiks tõsimeeli väita, et ,[f]ormalistid tõid käibele arusaama aktiivsest, vormivast vormist, mis passiivsele ainele rakendudes $\mathrm{ku}$ jundab sellest kunstiteose" (lk 341), sest arusaam passiivsest ainest/mateeriast ja aktiivsest vormist juurdus õhtumaises paradigmas lähtuvalt Aristotelesest."” Igale arusaamissooviga lugejale peaks kontekstist päevselge olema, et silmas peetakse niisuguse vormimõiste kinnistumist oma aja kirjandusteoorias ja selle vastandumist kooliõpetuse arusaamale, et vorm on väline kest.

MÄRT VÄLJATAGA

${ }^{7}$ Samas, lk 138. 